\title{
HEARTBEATS OF SOMATIC MEMORY: A REVIEW OF JONA- THAN LETHEM'S DISSIDENT GARDENS
}

The third chapter of Dissident Gardens (Doubleday, 2013), Jonathan Lethem's decade-hopping novel about three generations of a radical family in New York City, is called "Cicero's Medicine." The time is nearly the present, and the setting is amid the waves of the Atlantic Ocean. Sergius Gogan is a forty-something music teacher at a Quaker boarding school in Philadelphia who is pursuing research about his left-wing parents and grandparents. He has just come to the coast of Maine to interview Cicero Lookins, a fifty-sixyear-old cultural studies professor at the small, rural college of Baginstock. When the two middle-aged men discover that the late September day is to be exceptionally hot, they decide to converse while swimming in the ocean that Cicero regards as medicinal.

Sergius is the son of Miriam Zimmer and Tommy Gogan, New Left radicals assassinated in Nicaragua by a U.S.-backed counter-revolutionary band at the time of the 1979 revolution. He is also the grandson of Rose Angrush and Albert Zimmer, Jewish Americans of the 1930s generation ill-treated by the Communist movement. Rose, an ungovernable force of class-conscious rage, was ejected in 1955, ostensibly for endangering the organization's security through a sexual impropriety. Eight years earlier, the semi-aristocratic Albert was accused by his comrades of spying for the government and then mysteriously sent to East Germany to work for the Stasi. Another person of interest is Lenin (called Lenny) Angrush, Rose's nephew and Miriam's first cousin. Unrequitedly in love with Miriam, Lenny is a Communist chess hustler who dreams of managing a proletarian baseball team until he is killed by a gang.

Cicero is no blood relative of Sergius. He is the child of one of Rose's married lovers from fifty years earlier, a huge African-American policeman named Douglas Lookins. Rose met Douglas at the height of the Cold War when a neighborhood citizens' patrol was formed; their romantic relationship served as the pretext for her expulsion from her Communist Party unit at the hands of Sol Eaglin, a jealous comrade who preceded Lookins as her married lover. At the start of her adulterous affair with Douglas, Cicero was in utero. Diane, his sickly biological mother, dies some years later, but he is 
informally adopted by Rose before elementary school. Although Cicero has a bitter break with Rose at the time he departs for college at Princeton, he re-establishes their relationship after his father passes and as she lapses into senility and eventually death.

Cicero has an African-American family history of his own to negotiate, but the above-mentioned ties to Rose, his mentor and tormentor, render him uniquely qualified to be a principal source of information for Sergius. The latter is pictured in the salt water as a "helpless pink balloon adrift atop gibbous squiggles of his own reflection," sad-faced and haunted by half-memories of family lore. Most of these revolve around Rose's lonely imperiousness during her decades of living in Sunnyside Gardens, a community housing project in the borough of Queens that was catnip to Jewish leftist families. Of his own parents, buried in Nicaragua when he was six, Sergius recalls almost nothing. Yet as a guitar instructor, he shadows his father's profession as a Greenwich Village folksinger.

While the white and black heads of Sergius and Cicero bob in an ocean described by Lethem as a "memory sea," the former explains his project: "I 176 plan to write a cycle of songs. About the Gardens, about Rose and Miriam, and Tommy." This goads Cicero to an impassioned rant about Rose as a resentful woman, power-hungry for emotional control: "She wanted to free the world, but she enslaved any motherfucker she got in her clutches. Now go back to Philly and write yourself a song cycle about that." Yet even as he speaks, Cicero feels himself succumbing to "the heartbeat of somatic memory," a flashback to earlier feelings. For an instant he relives the experience of being propelled by Rose through the streets of Sunnyside at age six or seven, then reanimates her ghost in the cinema of his imagination where she both ridicules his sexual orientation (he is gay) and commands him to cooperate with Sergius. The insinuation is strong that Cicero, whose Atlantic Ocean medicine is now contaminated by Rose's "spirit animal," will provide much of the raw material generating the loosely linked sequence of recollected incidents in the three hundred pages of the novel that follow.

The parallels between the fictional quest of Sergius in Maine and the origins of Dissident Gardens are inescapable. Like Sergius Gogan, Jonathan Lethem was fortyish when he undertook his own writing project inspired by family history (this novel). Sergius was named by his parents for Norman Mailer's Sergius O'Shaugnessy, the sexual adventurer of "The Time of Her Time" in Advertisements for Myself (1959), and Lethem has acknowledged a 
lifelong fascination with Mailer and his persona, publishing concurrently an introduction to Mind of An Outlaw: Selected Essays of Norman Mailer (2013). Lethem's maternal grandparents were of an ancestry similar to the Zimmers (Jews from Germany and Eastern Europe) and resided in Sunnyside Gardens. His maternal grandfather, like that of Sergius, left his wife and repatriated to Eastern Germany in the late 1940s. His mother, Judith, was also a political activist who died young, and his father, Richard, a cultural radical (in this case an avant-garde artist) whose vocation Jonathan at first tried to emulate. Sergius is raised in a hippie-radical commune in Alphabet City in Manhattan; Jonathan grew up in a similar commune in North Gowanus in Brooklyn.

Even the discrepancies are provocative when counterpoised. Sergius's mother is killed when he is six, while Lethem's mother died of a brain tumor when he was nine; but it was several years earlier that the novelist's parents were divorced, a traumatic event that corresponds to the time of the disappearance of Miriam and Tommy Gogan in Dissident Gardens. Lethem's main source of family history is his father, to whom the novel is dedicated, a fictional role assumed by the prodigious African-American homosexual, Cicero, who jokes about serving as Sergius's "Bagger Vance" - the Will Smith film character who helps Matt Damon overcome personal demons in order to golf once more. Unable to determine if his grandmother was actually a Party member or even technically expelled, Lethem speculates in an NPR interview (September 9, 2013) that her painful separation from the movement was actually a result of humiliation when she belatedly discovered the delusional nature of her belief in Stalinism in 1956. Most reviewers of the novel have missed another peculiarity, one that teases the political imagination: the title "Dissident Gardens" is explained in the text only in reference to East Germany's Werkhofinstitut Rosa Luxemburg, not to Sunnyside. This is a residence and workplace on the outskirts of Dresden, spared from wartime firebombing and inhabited in the 1970s by Albert Zimmer and his second wife.

Jonathan Lethem is far from the first novelist to have unlocked the farcical potential of American radicalism, to demonstrate that even the most committed of radicals live in a chaos of concealed passions, to grasp a connection between characters' neuroses and public disorders of the day, or to trace the ambiguous escape route of the spoor of the Left tradition from Stalinist orthodoxy to the 1960 s and beyond. Philip Roth, E.L. Doctorow, Helen Yglesias, Ralph Ellison, Walter Mosley, Nora Eisenberg, John A. Williams, 
K.B. Gilden, Brian Morton, Paul M. Levitt, and Chaim Potok head a long list of authors uncovering such zones of anxiety. But most of these mainline the European novel of ideas into the veins of American literature, devoting part of their energies to establishing a compelling visible world. They take Communism as a creative challenge and artistic opportunity to reimagine human frailties in a social universe. In contrast, Lethem builds an indulgent memorial to his own life. He offers private demons and the painful personal relations of his interrelated characters as surrogates for what so many "actually, existing" radicals imagined to be transcendence through political commitment. Once again we are told that ideals are the most absurd of vanities, which is probably half-true but only flirts with the depths of psychological understanding required to write a novel about the Left. Lethem never gives the fish its hook.

What is valuable in Dissident Gardens is that it shows how the radical past looks from our particular present. After all, stories of the enigmatic Communist experience are never definitively told; they have a way of getting buried and swept aside for a time, then come back in new forms. Lethem's 178 particular forte in this unique tradition of retelling is his staccato-hip writing, a trendy high-octane style that is a prose equivalent of break dancing: "Yet Cicero, seated on a stool at Dave's on a cool November day in nineteensexual-position, Cicero at the corner of Canal and Broadway at the dawning of Aquarius yet with not a single one of his planets dignified, Cicero with his head nearly exploding with the reverberations of what Rose Zimmer's daughter has instilled in him one afternoon..." Lethem may hail, like many of his literary forbearers, from a politically radical tribe, but his own sensibility is rooted in marijuana and punk rock, not Camp Unity and Pete Seeger. When turning the pages of Dissident Gardens, think Philip K. Dick and Star Wars, not Gorky and Malraux. Cicero's "somatic memory" is a suitable image for the way Lethem enters the past, ready-made for a generation of readers who want things in fragments, sound bites, and tweets, and who will themselves connect (or not connect) the dots.

And here is where I unchain my inner Michiko Kakutani. The result is mostly an annoying read, as if popular culture were revenging itself on the history of the Left. I can't go so far as to say that Jewish-American radicalism has become the victim of a literary crime; there are episodes of splendid energy in the book, and we are lucky that Lethem came from a colorful family. Yet he is an acute observer of the morals and manners of subcultures of 
the Left only up to a point. His characters fail to develop beyond Sherwood Anderson "grotesques," solitary eccentrics distorted by an inability to fully express themselves. And the literal and figural blur too often; is he describing actual events in lives or their hallucinatory echoes?

Lethem is a noted genre-bender, but this novel swings too readily between a conventional costume drama (at its worst, politico-cultural AstroTurf) and a smorgasbord of insights and anecdotes. There may well be a yearning for good buried beneath the debris of disillusion that Lethem piles up, but it is hard to see, and his relentless sentences and absurd sense of humor ward off deeper pursuits. Skilled at foreboding rhetoric ("The true Communist always ends up alone," "every cell is infiltrated in the end"), Lethem unleashes a carnival of sensations and cascading adjectives that some readers may find monolithic and exhausting. Lethem has a great gift for launching ideas, but they falter in their realization, lacking concentrated imaginative attention. The somatic memories roiling up from "Cicero's medicine" yield a hyperawareness unmoored from historical consciousness, the essential ingredient for enhanced wisdom about the emotional landscape of radical commitment. 